Acta Poetica 28 (1-2)

PRIMAVERA-OTOÑO

2007

\title{
Ángeles en el abismo. Las imágenes dialécticas de Walter Benjamin y José Revueltas
}

\author{
Rogelio Espinoza
}

\begin{abstract}
“Ángeles en el abismo. Las imágenes dialécticas de Walter Benjamin y José Revueltas" plantea paratopías textuales y existenciales en ambos autores. El hilo conductor es el concepto de "imagen dialéctica" de Benjamin y de "realismo dialéctico" de Revueltas. El objetivo principal del artículo es realizar una exploración de ambos autores en el terreno común de la filosofía, la historia y la literatura, enmarcando problemas concretos en torno a la teología y el marxismo como fuentes de inspiración para analizar la alienación y la redención de la sociedad de masas moderna.
\end{abstract}

"Angels in abyss. Dialectic images of Walter Benjamin and José Revueltas" sets forth textual and existential paratopics in both authors. The thread of the present essay is the concept of Benjamin's "dialectic image" and Revueltas' "dialectic realism". The main objective lies in an exploration of both authors in the common field of philosophy, history and literature, framing concrete problems in relation to theology and marxism as sources of inspiration with the purpose to analize the topics of alienation and redemption of the modern mass society. 

Acta Poetica $28(1-2)$

PRIMAVERA-OTOÑO

2007

Rogelio Espinoza

FFyL, UNAM

\section{Ángeles en el abismo. Las imágenes dialécticas de Walter Benjamin y José Revueltas}

Me gusta imaginar a Walter Benjamin y a José Revueltas como esos ángeles vagabundos del guión de Peter Handke en El cielo sobre Berlín de Wim Wenders. Dos rastreadores incesantes e insaciables de los signos del mundo y sus desengaños, que dialogan entre sí a través de imágenes escritas mientras deambulan por el laberinto urbano; no para crear una teología negativa en una época - por supuesto la nuestra- en la que resulta imposible hablar positivamente, sino para hacer esa política de imágenes que devuelve la historia a los vencidos, para describir a ese ángel respondiente — ese retrato que habla- y es literatura.

En el extraño fragmentario Dirección única dedicado a Asja Lacis, en el que Benjamin sentenció "convencer es estéril", relata un sueño titulado "Embajada mexicana". ${ }^{1}$ Ahí, el filósofo asiste a una expedición científica en la que penetra en "una selva virgen de árboles muy altos" y avanza por "un sistema de cuevas al pie de una montaña", donde una orden de misione-

\footnotetext{
${ }^{1}$ Walter Benjamin, Dirección única, Madrid, Alfaguara, 1987, p. 23.
} 
ros convierte a los indios. Benjamin está en una "inmensa gruta central, rematada por una bóveda gótica", donde se celebra un antiquísimo ritual en el que un sacerdote indígena eleva un fetiche ante un busto de madera de Dios Padre, que enigmáticamente niega tres veces. Testigo o destinatario, Revueltas afirmó - tal vez con impaciencia pero bien despierto- que nunca conoció ángeles, en cambio, sostuvo toda su vida que: "el Paraíso es la lucha".

Poco o nada parecen tener en común Walter Benjamin (1892-1940) y José Revueltas (1914-1976) en sus trayectorias intelectuales y vitales. El primero, un eminente teórico judíoalemán que unió en rigurosos palimpsestos teóricos la literatura y la filosofía con la cábala judía; los juguetes de la infancia y el hachís con el París de Baudelaire. Sin duda, el crítico literario más original y provocativo de entreguerras en lengua alemana vislumbró que todo documento de cultura es también un nuevo documento de barbarie (Tesis sobre el concepto de historia, VII). Más modesto, pero no menos complejo en sus afanes intelectuales, Revueltas se definió a sí mismo como "un lector de su tiempo a la vez que participante activo de sus luchas". ${ }^{2}$ Fue un narrador que exploró todos los géneros narrativos a su alcance: el teatro, la crónica, la novela y el cine. Teórico y artífice de un proyecto narrativo sin parangón en América Latina: el realismo dialéctico, que desarrolló como una crítica a la idea del arte en tanto reflejo mecánico de la realidad y sus mistificaciones estéticas y políticas, que le costaron la

\footnotetext{
${ }^{2}$ Henry Lefebvre señaló en su prólogo a la Dialéctica de la conciencia la audacia de Revueltas por su intento de fundar la dialéctica en la subjetividad, empeño que lo situaba en la misma línea de investigación que Theodor W. Adorno en su Dialéctica negativa, aventurando que Revueltas "merece la misma reputación de los trabajos que van en este sentido, particularmente los de la escuela de Frankfurt", pues, apegado a las categorías hegelianas, se ocupaba de mostrar "en acto las contradicciones", es decir, "actuando en la conciencia... como un complejo y contradictorio nudo de relaciones con 'el otro', de iniciativas, de memoria, de adhesión al presente, de proyectos para el tiempo por venir". Cf., Henri Lefebvre, "Prólogo" a Dialéctica de la conciencia, México, Era, 1970, p. 14.
} 
animadversión y censura del partido comunista. Durante casi tres décadas Revueltas recorrió, entre la fidelidad y la ruptura, el laberinto cosificador del partido y reconoció la cárcel como un equivalente preciso de la sociedad, describiendo su experiencia con un lenguaje mistérico, afanado en exponer la persistente indeterminación de la temporalidad histórica.

Por supuesto, no se conocieron y ninguno supo de la existencia del otro ni de sus escritos. Sin embargo, al citarlos juntos, sus nombres nos dicen algo, nos hablan desde un cúmulo de imágenes que los emparenta: Ambos fueron atesoradores de la infancia y eminentes lingüistas adánicos, obsesivos descriptores y empecinados exploradores de la experiencia; de naturaleza rebelde y melancólica, se encontraban armados de poderosas inteligencias que de suyo chocaron con una marea de desaprobación académica que los precipitó al abismo intelectual. Precisamente, en 1925, cuando Revueltas deja para siempre las aulas -el Instituto Alemán, hoy Goethe- y comienza su búsqueda autodidacta en la Biblioteca Nacional, Benjamin es desahuciado académicamente luego de que su tesis doctoral o Habilitation, El origen del drama barroco alemán [Ursprung des deutschen Trauerspiels] fuera calificada como "incomprensible" por dos confundidos profesores de la Universidad de Frankfurt.

A la madurez del filósofo corresponde la juventud del escritor. La última y más aciaga década de Benjamin fueron los años treinta, época de ascenso del fascismo en Alemania y la etapa formativa de la Teoría Crítica desarrollada en el Instituto de Estudios Sociales de Frankfurt. Cuando en 1940 Benjamin termina con su vida en el pueblo fronterizo de Port Bou, intentando cruzar hacia España con la esperanza de llegar a Nueva York, donde lo esperan Theodor W. Adorno y Max Horkheimer, Revueltas comienza su trabajo como escritor dando forma literaria a sus dos encierros adolescentes en las Islas Marías con Los muros de agua. En sus novelas, Revueltas volverá 
una y otra vez a sus experiencias como militante comunista en los años treinta en El luto humano (1943) y la trilogía de lo marginal político: Los muros de agua (1940), Los días terrenales (1949) y Los errores (1964).

Ni contemporáneos ni ajenos, ambos escritores se definieron marxistas, pero sobre todo revolucionarios, técnicos de la ruptura, profesionales de la grieta y el quebranto. Fueron señalados como heterodoxos y estetas irresponsables - Benjamin reconvenido por Adorno, Revueltas por Neruda. Abrevaron de la Biblia, el marxismo y Marcel Proust; amaron a Kafka palpando en sus páginas que la esperanza sólo proviene de los que no tienen esperanza; leyeron atrevidamente la historia a contrapelo y viajaron a Moscú en curiosas circunstancias: Benjamin entre 1926 y 1927, por una calle de dirección única llamada Asja Lacis — al inicio de la debacle trotskista— para escribir un artículo sobre Las afinidades electivas de Goethe y Revueltas en 1935, junto a Vicente Lombardo Toledano, en las vísperas de la hecatombe de los Procesos de Moscú. Como aprendices de brujos recorrieron la Meca comunista. Benjamin lo hizo desesperando rápidamente del proceso de burocratización, Revueltas afirmando no haber visto nada extraño, ningún síntoma de las Purgas. Tres décadas después, en Los errores, expuso el caso del camarada Emilio Padilla, en realidad Evelio Vadillo, militante mexicano que conoció en las Islas Marías y milagrosamente sobrevivió a los campos de exterminio ideológico del estalinismo.

Lejanos y cercanos a la teleología comunista y por ello críticos de su mistificación, ambos escritores asumieron los márgenes de la literatura y la filosofía como el verdadero material apofántico de la realidad. Frecuentemente se les ha adjudicado - ya sea por descalificación o uso- un supuesto trasfondo religioso, tal vez porque paradójicamente se negaron a identificar al sujeto histórico con el mecanismo de la verdad invencible, prefiriendo buscar con frenesí los días terrenales de un 
sujeto metafísico — las masas y sus imágenes - en las pululantes metrópolis de París, Berlín o México. Así, convertidos en flâneurs o "iluminados profanos" buscaron ese "instante de peligro", en que según Benjamin se contempla la historia como "perfecta actualidad", es decir, como un pensar y obrar en imágenes en que se juega agónicamente la ruina o la redención histórica — el lado moridor revueltiano.

Como ha señalado Sigrid Weigel en Cuerpo, espacio e imagen en Walter Benjamin es precisamente en esas imágenes de la historia en que se expresan, más allá de la oposición entre forma y contenido, lo realmente específico de la configuración teórica benjaminiana que consiste en "pensar en imágenes, en las referencias a esas imágenes de la historia y, sobre todo, en el trabajo teórico y linguiístico que ellas llevan consigo". ${ }^{3}$ Desde esta perspectiva, los modos de escribir y de pensar en los dos escritores se tornan compatibles y desembocan en la imagen. Benjamin la llamó "el tercer elemento" [ein Drittes], y la define no como una copia, ni una traducción o una 'puesta en clave', sino como una constelación heterónoma y heterogénea en que las figuras de pensamiento se amalgaman con las de la historia, con las de la experiencia o las de la realidad. Palabra, memoria y acto se fusionan en imágenes fugitivas que constituyen vías privilegiadas de acceso para la comprensión histórica.

Este interés fundante por la imagen fue muy estimado por Revueltas, quien apuntó en El lenguaje cinematográfico y sus problemas (1965) que:

Las "imágenes" del cinematógrafo, si se toma la palabra imagen en su sentido más general y abstracto, como un cierto género de representación del conocimiento, no son diferentes en esencia a las imágenes de la poesía, la pintura o la novela. El

\footnotetext{
${ }^{3}$ Sigrid Weigel, Cuerpo, imagen y espacio en Walter Benjamin, Buenos Aires, Paidós, 1999, pp. 11-12.
} 
procedimiento ordenador es el mismo, el sistema de "transustanciación" de los elementos, no difiere: el pan y el vino se convierten en cuerpo y sangre merced a un idéntico milagro emocional. ${ }^{4}$

Influenciado por las ideas del cineasta ruso Sergei M. Eisenstein, Revueltas elevó el montaje, es decir, la yuxtaposición de imágenes, a la categoría de método universal de las artes y, especialmente, de los lenguajes narrativos hegemónicos del siglo xx, la pareja poligámica del cine y la novela. Para Eisenstein el montaje dialéctico se originaba por una yuxtaposición de oposiciones, un "montaje a saltos" que implicaba la determinación de 'puntos señalados' y de 'momentos privilegiados' que procede por alternancia de conflictos, resoluciones y resonancias. ${ }^{5}$ Benjamin, que conoció las ideas del cineasta ruso, arriesgó una definición semejante de "imagen dialéctica", que consiste en "[una] imagen de una estructura contra la corriente y en una imagen de pensamiento [Denkenbild] de dos fuerzas que, aunque en direcciones contrarias, pueden transmitirse energía una a la otra hacia su respectiva dirección". ${ }^{6}$ En una carta a Theodor W. Adorno, Benjamin precisó que:

Al extinguirse su valor de uso, las cosas alienadas quedan vaciadas y adquieren significaciones cifradas. De ellas se apodera la subjetividad, que introduce en ellas intenciones de deseo y miedo. Dado que las cosas muertas sustituyen como imágenes a las intenciones subjetivas, éstas se presentan como no perecidas y eternas. Las imágenes dialécticas son constelaciones entre las cosas alienadas y la significación exacta, detenidas en el momento de la indiferencia de muerte y significación. Mien-

\footnotetext{
${ }^{4}$ José Revueltas, El conocimiento cinematográfico y sus problemas, México, Era, 1982, p. 19.

${ }^{5}$ Cf., Sergei M. Eisenstein, El sentido del cine (1947), México, Siglo XXI, 1976, pp. 12-14.

${ }^{6}$ Sigrid Weigel, op. cit., p. 37.
} 
tras que en la apariencia las cosas despiertan a lo más nuevo, la muerte transforma sus significaciones en lo más antiguo. ${ }^{7}$

Para ilustrar el acercamiento entre los autores a partir de sus imágenes dialécticas vale la pena la relectura del tercer capítulo de Los días terrenales, sin duda la novela más influenciada, junto a Los errores, por las técnicas narrativas del montaje cinematográfico que Revueltas asimiló a partir de sus colaboraciones como guionista y adaptador entre 1945 y 1958. El capítulo narra el descensus ad inferos que los militantes comunistas Bautista y Rosendo realizan para pegar propaganda política en las inmediaciones del basurero cercano a la estación de trenes de Nonoalco-Tlatelolco. Revueltas reconstruye, a partir de imágenes dialécticas, policronías espaciales que conjugan en un solo espacio/tiempo las eras imaginarias del México prehispánico, colonial y moderno.

México trastoca, subvierte los puntos cardinales, y al mezclar el pan y el vino del tiempo y el espacio se transustancia en una unidad extraña que hace posible la convivencia de sucesos ocurridos hace cuatro siglos con cosas existentes hoy; piedras que ya existían en el año de Ce-Ácatl con campanas y fábricas y estaciones y ferrocarriles. Escuchó con atención de ciego, tenazmente, igual que un avaro, con una especie de sed. Voces que venían desde Tlatelolco, donde Zumárraga edificó el Colegio de los Indios Nobles, se escuchaban a más de dos o tres kilómetros, en la plaza donde los acróbatas de Moctezuma hacían el juego de El Volador; lamentos y silbatos provenientes de Popotla, de Azcapotzalco [...]. ${ }^{8}$

${ }^{7}$ Cf., José M. Cuesta Abad, La historia según Walter Benjamin, Juegos de duelo, Madrid, Abada, 2004, p. 80.

8 José Revueltas, Los días terrenales, ed. crítica Evodio Escalante, México, CNCA, 1992, p. 43. 
La historia presentada como una "escena de la memoria" se interrumpe cuando a lo lejos suena el reloj de la penitenciaría, extraño recordatorio del tiempo apandado, "vacío y homogéneo" (Tesis $X V$ ) que desarrolla la idea de que la conciencia del revolucionario es capaz de hacer saltar la continuidad histórica, como ocurrió durante la Revolución de julio de 1830. "Cuando cayó la noche del primer día de combate ocurrió que en muchos lugares de París, independientemente, y al mismo tiempo hubo disparos contra los relojes de las torres". 9

En el artículo de 1936, "El surrealismo. La última instantánea de la inteligencia europea", Benjamin anotó que la lectura de las imágenes suponía un auténtico "salto de tigre" en la "actualidad" o "tiempo de ahora", [Jetzeit] que permitió al surrealismo elaborar una política en imágenes y un arte expresivo capaz de anular "la separación entre un obrar poético y un obrar político", en el que se reconoce "lo cotidiano como impenetrable y lo impenetrable como cotidiano". Al final del ensayo sobre el surrealismo, Benjamin insertó la imagen del "despertador que cada minuto resuena durante cada sesenta segundos". Hace notar que las imágenes dialécticas son precisamente el despertador de la historia, un "tiempo opuesto al calendario" en que es posible leer la "actualidad del tiempo" capitalista en el cuerpo humano; pues como en la escalofriante imagen de Metrópolis de Fritz Lang, el cuerpo del operador, específicamente sus brazos, se fusionan con las enormes manecillas de la máquina, sin que podamos definir quién dirige a quién en el continuum de la producción.

Este mismo choque de fuerzas a partir de imágenes, pero esta vez referidas a la relación entre política y teología, se ilustra en la primer tesis en que Benjamin alegoriza al materialismo histórico como un autómata mecánico capaz de jugar par-

\footnotetext{
9 Walter Benjamin, Tesis sobre la historia y otros fragmentos, México, Contrahistorias, 2005, p. 28.
} 
tidas de ajedrez, y ganarlas todas, merced a un enano jorobado que lo manipula desde su interior.

1. Según se cuenta, hubo un autómata construido de manera tal, que, a cada movimiento de un jugador de ajedrez, respondía con otro, que le aseguraba el triunfo en la partida. Un muñeco vestido de turco, con la boquilla del narguile en la boca, estaba sentado ante el tablero que descansaba sobre una amplia mesa. Un sistema de espejos producía la ilusión de que todos los lados de la mesa eran transparentes. En realidad, dentro de ella había un enano jorobado que era un maestro en ajedrez y que movía la mano del muñeco mediante cordeles. En la filosofía, uno puede imaginar un equivalente de ese mecanismo; está hecho para que venza siempre el muñeco que conocemos como "materialismo histórico". Puede competir sin más con cualquiera, siempre que ponga a su servicio a la teología, la misma que hoy, como se sabe, además de ser pequeña y fea, no debe dejarse ver por nadie.

La leyenda transcrita por Benjamin recuerda mucho la descripción de Edgar Allan Poe en su ensayo "El jugador de ajedrez de Maelzel", ${ }^{10}$ publicado en 1836 en el Southern Literary Messenger, en que Poe dio a conocer el truco del famoso autómata conocido como "El Turco", construido en 1769 por el científico eslovaco Wolfang von Kempelen, (1734-1804) quien diseñó prototipos para miembros humanos artificiales y una máquina de escritura para ciegos, realizando exhibiciones del autómata en las cortes de Viena y Rusia, amén de derrotar en 24 jugadas a Napoleón. A la muerte de Kempelen, el aparato fue adquirido por Johann Nepomuk Maelzel que llevó al turco a una exitosa gira por Europa y la Costa Este norteamericana. El ensayo de Poe es precisamente la reconstrucción

\footnotetext{
${ }^{10}$ Cf., Irving Wohlfarth, Hombres del extranjero, Walter Benjamin y el Parnaso judeoalemán, México, Taurus, 1999, pp. 11 y ss.; Michel Löwy, Walter Benjamin. Aviso de incendio, Buenos Aires, FCE, 2003, pp. 37-52.
} 
animada del artilugio según un modelo de análisis operativo que permite poner en duda su cualidad de máquina pura, concluyendo con una serie de razonamientos lógicos que explican su falsedad.

A semejanza del cine que al soñar poéticamente es más realista, 11 "El jugador de ajedrez de Maelzel"12 produce el falso efecto de realidad sobrenatural: la inteligencia humana reproducida por el mecanismo es ficticia aunque el objeto fantástico que la "imita" sea "real". Los desplantes del autómata oriental frente a los autócratas ilustrados y su victoria sobre Napoleón acentúan el simbolismo de la obra que supera a su creador, y enfatiza la superioridad metafísica de lo técnico sobre la soberanía humana. Como señala Löwy en Aviso de incendio, su lectura de las Tesis sobre el concepto de historia, la conclusión de Benjamin es la de Poe: "No hay duda de que los movimientos del autómata son regulados por el espíritu y no por otra cosa". ${ }^{13}$

De manera que, si en la imagen de Metropolis ignoramos quién controla a quién en el tiempo de la producción, en la Tesis I de Benjamin ignoramos si el materialismo histórico ha sometido a la teología, o si en realidad la teología controla a sus espaldas los hilos del mecanismo. En la imagen podemos ver que la teología está al servicio del materialismo que gana todas las partidas, pero al mismo tiempo anima el aparato muerto, pues sin el pensamiento mesiánico el materialismo "no puede ganar". ${ }^{14}$ El fragmento muestra la contradicción dinámica y la no identificación de ambas imágenes y por ello su

\footnotetext{
${ }^{11}$ Walter Benjamin, La obra de arte en la época de su reproductividad técnica, México, Itaca, 2003, p. 64.

12 E. A. Poe, "Chess-player of Maelzel", Works, vol. IV, 1856, pp. 346-370. Vid., página de la Sociedad Edgar Allan Poe de Baltimore: <http://www.eapoe.org/ works/essays/maelzel.htm>.

${ }^{13}$ Michel Löwy, op. cit., p. 49.

${ }^{14}$ Cf., I. Wohlfarth, op.cit., p. 117; M. Löwy, op. cit., p. 52.
} 
lectura se complica siempre que queremos tomar partido unilateralmente.

En Revolución conservadora y conservación revolucionaria. Política y memoria en Walter Benjamin, Juan Mayorga señala que la imagen del jugador de ajedrez invierte la imagen que invoca; "si en la imagen el enano toma al turco a su servicio, en el texto sucede lo contrario". ${ }^{15} \mathrm{Si}$ en el juego visible de ajedrez el autómata tira con la mano izquierda/esclava en realidad la mueve la mano derecha/libre. ${ }^{16}$ La marioneta sólo juega con la mano izquierda porque el operador tiene que usar la derecha para controlar el mecanismo. Así, la primera tesis nos pone sobreaviso de las tensiones que hay que considerar para su lectura: "se trata de una tensa vinculación cuyo espacio común es la experiencia negativa de la actualidad histórica". ${ }^{17}$

En Los días terrenales y Los errores, Revueltas describió la realidad como un enorme torbellino o tifón en perpetuo movimiento del que acaso percibimos algunos jirones, fragmentos de una totalidad histórica en permanente ocultamiento y exposición deformada por nuestras acciones. Sin duda, Revueltas también conoció el ensayo sobre el jugador autómata, pues en el capítulo XVIII de Los errores nos presenta una reunión clandestina en el taller de una fábrica en que Eladio Pintos, un viejo militante trostkista perseguido por la Komintern, organiza la parte técnica de una huelga de transporte.

Rendía el informe Eladio Pintos, en medio de las sombras inmóviles y atentas de los presentes, que la luz helada y agresiva de una lámpara de alto voltaje proyectaba sobre las paredes

\footnotetext{
15 Juan Mayorga, Revolución conservadora y conservación revolucionaria. Política y memoria en Walter Benjamin, México, Anthropos, UAM-I, 2003, p. 85.

${ }^{16}$ El descubrimiento de este detalle es la última cuenta del razonamiento de Poe: "A few more imperceptible steps lead us, finally, to the result. The Automaton plays with his left arm, because under no other circumstances could the man within play with his right —a desideratum of course". E. A. Poe, op. cit., pp. 269-270.

${ }^{17}$ Juan Mayorga, op. cit., p. 86.
} 
cubiertas con los más distintos impresos y grabados. Como un arroyo metálico que llevase en su corriente una complicada pedacería de alambres y cerraduras, el rumor del linotipo se escuchaba atrás de las palabras de Eladio Pintos, de un modo suave y distante, al que todos se habían acostumbrado. Desde un rincón, frente a su máquina, el linotipista, de rostro muy delgado, mejillas hundidas, la barba de varios días, tecleaba nerviosamente al componer el manifiesto del Comité Central de Huelga, pero con un desprendimiento tan completo en relación con los demás, que parecía una marioneta sonámbula a la que alguien estuviera manejando desde muy lejos con la ciega precisión de un ajedrecista. ${ }^{18}$

El Linotipista descrito como una marioneta que transcribe en su rincón como "si estuviera manejado desde muy lejos", cuando en realidad obedece a la voz que tiene frente a sí, establece una especie de equilibrio entre el desorden visual y auditivo que preside la escena: la lámpara de alto voltaje que proyecta y el rumor del linotipo que se escucha como fondo al discurso del estratega como nuevo "ajedrecista". Por otro lado, la voz de Eladio Pintos representa aquello que el partido pretende negar y, por ello, el papel del obrero de la letra parece ser el registro no sólo de la huelga de transporte que paralizará la ciudad, ${ }^{19}$ sino especialmente la voz que "cepilla la Historia a contrapelo". En realidad el Linotipista ha sido designado por el partido para asesinar por la espalda a Eladio Pintos, quien no es una máquina de creencias ideológicas, es decir, un autómata que cree conocer la "verdad histórica", sino un conocido

18 José Revueltas, Los errores, México, FCE, 1964, p. 172.

19 Los errores, como la mayoría de las novelas mencionadas, remite a coyunturas políticas y luchas sociales precisas, en este caso se habla del enfrentamiento entre miembros del Partido Comunista y el grupo fascista los dorados en el Zócalo de la Ciudad de México en 1935, en el que murieron cinco personas y cuarenta heridas. Vid., Evodio, "Circunstancia y génesis de Los días terrenales, en Revueltas, José, Los días terrenales, ed. crítica de Evodio Escalante, México, CNCA, 1992 (Archivos, 15), p. 194. 
militante internacional asignado por su dirección para dirigir el asalto a un local fascista en el que "misteriosamente" será asesinado por "traidores trostkistas". La ironía es evidente, el Linotipista tiene como misión acallar la voz de Eladio Pintos mientras finge elaborar su registro, una contradicción entre el personaje y la imagen que lo presenta.

En Los errores se unen dos mundos clandestinos, el de los militantes comunistas y el de los marginales del hampa de la ciudad de México, el Muñeco y Elena-no, un padrote y un enano homosexual que intentan asaltar a Don Vitorino, anticuario y prestamista antisemita de La merced y promotor del grupo fascista los dorados. A semejanza del enano teológico de la primera tesis Elena-no se introducirá dentro de un baúl, mientras El muñeco se disfrazará de agente viajero y encargará su "mercancía" al usurero para que durante la noche el enano deje entrar a su cómplice. El enano desobedece a El muñeco y mata al prestamista, por su parte El Muñeco se deshace del enano arrojándolo dentro de la maleta al desagüe público, precisamente en el momento en que ebrio de poder cree dominar el mundo. Si bien es seguro que Revueltas no conoció las Tesis sobre el concepto de historia, parece que la historia del autómata ajedrecista le era también significativa.

Revueltas expresó el deseo de que su obra literaria fuera compilada bajo el título genérico de Los días terrenales, título de la novela en que realizó una profunda autocrítica de su militancia en los años treinta y presenta el debate entre el dogmático Fidel Serrano, miembro de la dirección del partido, y Gregorio Saldívar, el militante esteta que afirma: “ ¡Luchemos por una sociedad sin clases! ¡Enhorabuena! ¡Pero no para hacer felices a los hombres, sino para hacerlos libremente desdichados, para arrebatarles todo esperanza, para hacerlos hombres!".20

${ }^{20}$ José Revueltas, Los días terrenales, pp. 131-132. 
Reconocimiento de que el comunismo no traería la riqueza generalizada, sino el reparto de la miseria común. Auténtica búsqueda de un conocimiento de lo humano en el error y en el errar histórico que supone una toma de posición responsable con la totalidad de lo otro, y en el que puede detectarse el eco de un pensador que Revueltas tampoco conoció, Emmanuel Levinas.

Me pueden horrorizar todas las inauditas crueldades de los nazis en Alemania o de los japoneses en China, pero yo, Gregrorio Saldívar, soy culpable de ellas porque esas crueldades las han consumado hombres como yo. Me avergüenzo por mí mismo de que las guerras existan; me avergüenzo por mí mismo, y no tengo exculpante que me valga, a causa de todos los crímenes, las bajezas, las ruindades, los pecados que se cometan en no importa qué parte de la tierra por los hombres, por mis semejantes. Y nada de buscar consuelo en la idea de que, en cambio, yo soy un ser moral, noble, recto y demás. ¡Nada de eso! Soy responsable de los otros como de mí mismo. ${ }^{21}$

Terry Eagleton definió el empeño de Benjamin por buscar el cuerpo onírico de la realidad, su intención de "leer el mundo", como una "somática política", es decir, como la intención por analizar detalladamente la producción política y visceral del cuerpo histórico. La idea de una "somática política" montada a partir de "imágenes dialécticas" es sin duda aplicable a José Revueltas, por lo que valdría la pena intentar desarrollar esta perspectiva de estudio con más detalle. Por lo pronto, valga este acercamiento como guía del hipotético encuentro de dos ángeles en el abismo.

${ }^{21}$ Ibid., p. 146. 


\section{BIBLIOGRAFÍA}

Benjamin, Walter, "El surrealismo. La última instantánea de la inteligencia europea", en Imaginación y sociedad, Iluminaciones 1, Madrid, Taurus, 1980.

- Dirección única, Madrid, Alfaguara, 1987.

- La obra de arte en la época de su reproductividad técnica, México, Ítaca, 2003.

- Tesis sobre la historia y otros fragmentos, México, Contrahistorias, 2005.

Cuesta Abad, José M., La historia según Walter Bejamin, Juegos de duelo, Madrid, Abada, 2004.

Eisenstein, Sergei M., El sentido del cine, México, Siglo XXI, 1976.

Escalante, Evodio, "Circunstancia y génesis de Los días terrenales, en José Revueltas, Los días terrenales, México, CNCA, 1992, (Archivos, 15).

Lefebvre, Henri, "Prólogo" a José Revueltas, Dialéctica de la conciencia, México, Era, 1970.

Löwy, Michel, Walter Benjamin. Aviso de incendio, Buenos Aires, FCE, 2003.

MAYORGA, Juan, Revolución conservadora y conservación revolucionaria. Política y memoria en Walter Benjamin, México, Anthropos, UAM-I, 2003.

PoE, Edgar Allan, "Chess-player of Maelzel", en Works, vol. IV, 1856, pp. 346-370. Véase página de la Sociedad Edgar Allan Poe de Baltimore: <http://www.eapoe.org/works/essays/maelzel.htm>.

Revueltas, José, Los errores, México, FCE, 1964.

- El conocimiento cinematográfico y sus problemas, México, Era, 1982.

- Los días terrenales, Ed. crítica de Evodio Escalante, CNCA, 1992.

Weigel, Sigrid, Cuerpo, imagen y espacio en Walter Benjamin, Buenos Aires, Paidós, 1999.

Wohlfarth, Irving, Hombres del extranjero, Walter Benjamin y el Parnaso judeoalemán, México, Taurus, 1999. 
